\title{
BASIS OF SUCCULENCE IN PLANTS
}

\section{T. MacDougal, H. M. Richards, and H. A. Spoehr}

Succulents may be characterized as plants in which the parenchymatous elements show an exaggerated development with relation to the more rigid tissues, and, unlike pith or medullary tracts, the masses of thin-walled cells remain distended and turgid. The liquid contents of such cells may or may not contain much dissolved material. The disposition of the water-holding tracts varies from leaves to stems and roots, but in all cases the most important general effect is one of massiveness, and the surfaces of succulent plants may in such forms as the barrel cacti bear the smallest possible proportion to the mass, that of a globe.

The ecologist recognizes two general types of succulents, those of the arid regions, which are of a xerophytic character, exemplified by the cacti; and the halophytes or fleshy seashore plants, also at home in alkaline areas. The plants of the two types are quite unlike in their transpiratory relations. The desert succulents may lose water so slowly that an existence of several years may be maintained upon the water in the thin-walled tracts. ${ }^{x}$ On the other hand, the halophytes or fleshy shore plants may flag and wilt as readily as any thin-leaved form, due to the rapid loss of water from the surfaces. The origination of these striking forms has been the subject of much speculation, but all attempts to connect succulency in a causal way with the presence of salts in the soil, or in the plant with the well known high acidity of many of these forms, or with any purposeful development of water storage capacity, have been inadequate.

Our concurrent observations and experiments may be briefly summarized as follows:

I. A Castilleja native to the region about the Coastal Laboratory, at Carmel, California, includes two habitat forms, genetically identical, one with thin leaves growing in the open forest formation,

${ }^{x}$ MacDougal, D. T., et al., End results of desiccation and respiration in succulent plants. Physiol. Researches I:289-325. I9I5. 
and another with fleshy leaves growing on the sandy foreshores under arid, but not saline, soil conditions. The succulent leaves owe their increased thickness to the enlargement of elongated cells vertical to the surface of the leaves.

2. The thin leaves show an acidity double that of the fleshy type, and have a relatively greater dry weight.

3. The fleshy leaves, fresh and in a dried condition, present swelling reactions similar to those of sections of the joints of platyopuntias, indicative of cells high in pentosans, or mucilages. The behavior of these organs is different in many important particulars from that of thin leaves, which swell more in acid than in alkaline solutions, the reverse taking place in succulent leaves, in parallelism to Opuntia.

4. Differences in the swelling reactions of dried leaves of both kinds are to be ascribed to the adsorption of the contained acids and salts of different amounts in the two cases on cell colloids, high in pentosans in one case and hence presenting characteristic coagulatory effects.

5. It has been established by researches not described in this paper that the reduction of the water content of the cell below a certain point results in the conversion of polysaccharides, which do not show a high imbibition capacity, to pentosans, which mixed with nitrogenous substances have an enormous hydration capacity.

6. Succulence, therefore, may originate as it is seen to occur in Castilleja as a direct result of aridity. Species of Ericameria and Erigeron with a distribution similar to Castilleja display thin and succulent leaves corresponding in the same manner to the environment.

7. High acidity may not be taken as a result of succulence. It is probably more nearly correct to assume that succulence may develop only in plants which have a carbohydrate metabolism characterized by large acid residues.

The bulk and durability of succulents have made them readily available for chemical studies, and these features are responsible in part for the fact that carbohydrate metabolism and respiration, photosynthesis, the formation and fate of acids, the oxygen-carbondioxide ratio, and other features have all received contributions 
based upon researches carried out with the fleshy plants. ${ }^{2}$ The amount of detailed and systematic information concerning these plants as a type is probably greater than that of any other ecological group, and it is evident that their metabolism presents some definite characteristic aspects. It is upon the basis of such knowledge that it becomes possible to formulate the generalizations set forth in this paper.

The only comparisons between succulents and non-succulents that have been possible have lacked directness because the reactions of different species could not be rated against each other with accuracy. The final and necessary conditions for a critical discussion of the matter, that of succulent and non-succulent individuals of the same species, finally came to the attention of the authors in the case of Castilleja latifolia at Carmel, California, in the summer of I9I8. One form of this plant which grows on the edge of the bluff overlooking the beach, or within $25 \mathrm{ft}$. of it, has succulent leaves of considerable thickness which are usually pale green. The other, which grows farther back on the foreshore, has a thinner, mesophytic type of leaf which is darker green and more hirsute than the succulent type. This is probably the typical form of the manuals and is similar to the one which grows farther back in the pine woods. A notable exception as to the relative region of growth of these 2 forms was found in a luxuriant growth of the thin-leaved type at the base of the beach bluff on the edge of the sand. Examination showed that this was unquestionably due simply to the ample water supply from the seepage at the base of the cliff. It becomes evident, therefore, that the difference in the succulent and mesophytic habit is not a case of even partial halophytism, for if salt were present anywhere it would be at the cliff base. The contrasting habit is one rather of xerophytism versus a mesophytic growth.

The members of the genus are reported to be parasitic, and individuals with thin and others with succulent leaves were found

${ }^{2}$ Spozhr, H. A., Photochemische Vorgänge bei der Diurnalen Entsäurung der Succulenten. Biochem. Zeitsch. 57:95-I I I. I9I3.

Richards, H. M., Acidity and gas interchange in cacti. Publ. no. 209. Carnegie Inst. Wash. I9I5.

Hempel, Jenny, Buffer process in the metabolism of succulent plants. Compt. Rend. Carlsberg. I3: no. I. I917.' 
with minute roots attached to the older tapering roots of Artemisia pycnocephala, in a manner indicating that the dependent nutritive relation is not an important one. That the appearance of succulence in this plant has no connection with its parasitism is supported by the fact that a similar state was found in Erigeron glaucus and Ericameria ericoides which are found in the locality near Castilleja.

Measurements of the thickness of the leaves of the two types show that the thin leaf averages about $0.5 \mathrm{~mm}$., while the succulent one ranges from I to $1.5 \mathrm{~mm}$. Examination of sections shows that the structure of the leaves is mainly differentiated by the size of the cells. While nearly dorsiventral in position when young, structurally the leaves appear almost bifacial, with 2 or 3 rows of vertically elongated cells on each face. In the thin-leaved type these cells are about $35 \times 25 \mu$, while similar cells of the succulent leaf are $\operatorname{10} \times 30 \mu$. Thus the increased thickness of the leaf is due chiefly to the enlargement of the cells vertical to the flat surface of the leaf.

There is naturally a disparity in the relation of fresh to dry weight in the 2 forms. Averages of a number of determinations show the following figures: mesophytic type, I gm. fresh young leaves, ०. I93 dry weight; succulent type, I gm. fresh young leaves, ○. I 3 dry weight. In general the succulent type yields only threefifths dry substance per unit fresh substance compared with the other form.

The acidity relations are also different. The succulent leaves are much less acid than the thinner ones. In table I averages of 10 or more determinations indicate the difference in acid extracted, and also the amount of water absorbed after 24 hours' immersion. As might be expected, the acidity relation of the 2 forms approximates more closely when reckoned according to dry weight than on the basis of fresh weight. Even then, however, the young active leaves show a considerably greater acidity in the thin type, a notable departure from our preconceived conceptions of acidity in relation to succulence. It may be said, however, that direct comparisons of acidity of a plant of the same species in a mesophytic and succulent condition do not seem to have been made. 
In connection with the swelling measurements described later, it became important to ascertain how much acid would leach out during immersion in water. Table II indicates the averages of a considerable number of series.

It is noticeable that the total amount of acid is somewhat greater than the figures previously given, due very possibly to the formation of acid during immersion in water, which might be caused

TABLE I

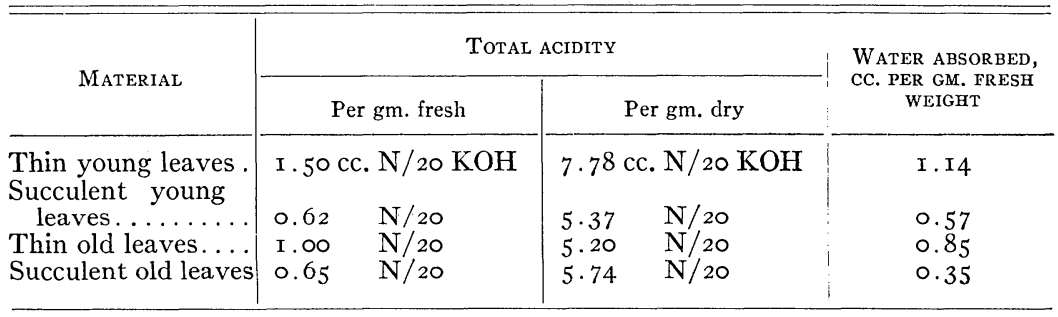

\section{TABLE II}

LEAVES IMMERSED IN WATER FOR 24 HOURS AT $17^{\circ} \mathrm{C}$.

\begin{tabular}{|c|c|c|}
\hline Material & $\begin{array}{l}\text { Acid diffused out per gm. } \\
\text { fresh weight }\end{array}$ & $\begin{array}{l}\text { Acid retained in tissue } \\
\text { per gm. fresh weight }\end{array}$ \\
\hline 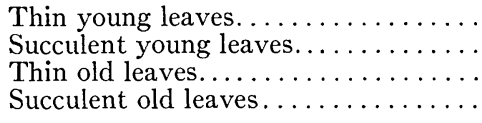 & $\begin{array}{ll}\text { I. } 30 \text { cc. } \mathrm{N} / 20 \mathrm{KOH} \\
0.55 & \mathrm{~N} / 20 \\
0.62 & \mathrm{~N} / 20 \\
0.30 & \mathrm{~N} / 20\end{array}$ & $\begin{array}{ll}0.39 \text { cc. } \mathrm{N} / 20 \mathrm{KOH} \\
0.28 & \mathrm{~N} / 20 \\
0.66 & \mathrm{~N} / 20 \\
0.4 \mathrm{I} & \mathrm{N} / 20\end{array}$ \\
\hline
\end{tabular}

by the exclusion of oxygen. It is also to be observed that the residual acid in the young leaves is closely the same in both the succulent and thin-leaved type. It appears that in the old leaves proportionately less of the acid leaches out and more is retained in the tissues. Other series of experiments were undertaken to determine the rate at which the acid diffuses out, the results of which are given in table III.

During the first hours of immersion the amount of acid which passes out is small and nearly equal in each case. As prolonged immersion in water kills the leaves, it seems probable that very little acid escapes as long as the cells are alive. ${ }^{3} \quad$ Table IV indicates

${ }^{3}$ LaUk, E., Die Bedeutung der Elektrolyten fuer Quellungsprocess. Biochem. Zeitsch. 37: 15-58. I916. 
the length of immersion which the 2 forms can withstand and recover to a seemingly normal condition.

After I 2 hours' immersion in water all the thin-leaved shoots were killed; some of the succulent leaved shoots survived partly.

TABLE III

RATE OF DIFFUSION OF ACID IN TERMS OF CC. N/20 KOH PER GM. FRESH WEIGHT AT $I 7^{\circ} \mathrm{C}$.

\begin{tabular}{c|c|c|c|c|c|c|c|c}
\hline \hline Material & 3 hours & 6 hours & 9 hours & I2 hours & I5 hours & 24 hours & $\begin{array}{c}\text { Residual } \\
\text { acid }\end{array}$ & Total \\
\hline $\begin{array}{r}\text { Thin young } \\
\text { leaves........ }\end{array}$ & 0.10 & 0.20 & 0.27 & 0.30 & 0.15 & 0.05 & 0.30 & I.37 \\
$\begin{array}{r}\text { Succulent young } \\
\text { leaves......... }\end{array}$ & 0.10 & 0.12 & 0.18 & 0.15 & 0.05 & Trace & 0.23 & 0.80 \\
\hline
\end{tabular}

TABLE IV

\begin{tabular}{c|c|c|c|c}
\hline Material & I.5 hours & 3 hours & 6 hours & 9 hours \\
\cline { 2 - 3 } Thin young leaves..... & $\begin{array}{l}\text { All recov- } \\
\text { ered } \\
\text { All recov- } \\
\text { ered }\end{array}$ & $\begin{array}{c}\text { All recov- } \\
\text { ered } \\
\text { All recov- } \\
\text { ered }\end{array}$ & Some killed & $\begin{array}{c}\text { More than } \\
\text { half killed } \\
\text { Sbout killed } \\
\text { killed }\end{array}$ \\
\hline
\end{tabular}

TABLE V

SWELLING of LEAves of Castilleja AT $16^{\circ} \mathrm{c}$.

\begin{tabular}{|c|c|c|c|c|}
\hline Material & Water & $\begin{array}{l}\text { Citric acid } \\
0.01 \mathrm{~N}\end{array}$ & $\begin{array}{l}\text { Potassium } \\
\text { hydrate } \\
\text { o.or M }\end{array}$ & $\begin{array}{c}\text { Potassium } \\
\text { nitrate } \\
\text { o.or M }\end{array}$ \\
\hline Thin.... & $\begin{array}{l}\text { Percentage } \\
\text { I } 49\end{array}$ & $\begin{array}{l}\text { Percentage } \\
\text { I } 20\end{array}$ & $\begin{array}{c}\text { Percentage } \\
60\end{array}$ & $\begin{array}{c}\text { Percentage } \\
76\end{array}$ \\
\hline Succulent & I 43 & 95 & I 25 & 90 \\
\hline
\end{tabular}

The reactions of the succulent leaves are seen to present the general aspects of sections of joints of Opuntia discata grown at Carmel and tested at $16^{\circ} \mathrm{C}$. at Carmel, July i9ı. Swellings of dried slices are as follows:

\begin{tabular}{c|c|c|c|c}
\hline Material & Water & $\begin{array}{c}\text { Citric acid } \\
0.01 \mathrm{~N}\end{array}$ & $\begin{array}{c}\text { Potassium } \\
\text { hydrate } \\
\text { 0.0I M }\end{array}$ & $\begin{array}{c}\text { Potassium } \\
\text { nitrate } \\
0.0 \mathrm{M}\end{array}$ \\
\hline Fresh sections... & $\begin{array}{c}\text { Percentage } \\
\text { Dried slices..... }\end{array}$ & $\begin{array}{c}\text { Percentage } \\
\text { I0 }\end{array}$ & $\begin{array}{c}\text { Percentage } \\
\mathrm{II} .7\end{array}$ & $\begin{array}{c}\text { Percentage } \\
\text { I0.4 } \\
4 \mathrm{I} 7\end{array}$ \\
\hline
\end{tabular}


A set of sections were now prepared, and, after being swelled with reactions parallel to the preceding, were dried, and the expansion when immersed was calculated on the original thickness, as follows:

\begin{tabular}{|c|c|c|c|c|}
\hline Material & Water & $\begin{array}{c}\text { Citric acid } \\
0.01 \mathrm{~N}\end{array}$ & $\begin{array}{l}\text { Potassium } \\
\text { hydrate } \\
\text { o. or M }\end{array}$ & $\begin{array}{l}\text { Potassium } \\
\text { nitrate } \\
\text { o. OI M }\end{array}$ \\
\hline $\begin{array}{l}\text { Fresh sections . } \\
\text { Dried sections .. }\end{array}$ & $\begin{array}{c}\text { Percentage } \\
\text { I I . } 4 \\
\text { I } 7.5\end{array}$ & $\begin{array}{c}\text { Percentage } \\
6.4 \\
26.4\end{array}$ & $\begin{array}{c}\text { Percentage } \\
6.6 \\
24.5\end{array}$ & $\begin{array}{c}\text { Percentage } \\
9.2 \\
22.4\end{array}$ \\
\hline
\end{tabular}

Determinations were also made of the escape of acid from dried leaves, which, as shown in table VI, is much more rapid than with the living material. It will be seen that the total of the acid extracted from the dried leaves is much less than that obtained from fresh leaves, which, as might be expected, indicates that some of the

TABLE VI

ESCAPE OF ACID FROM DRIED LEAVES IN TERMS OF CC. N/2O KOH PER GM. FRESH WEIGHT AT $17^{\circ} \mathrm{C}$.

\begin{tabular}{|c|c|c|c|c|c|c|c|}
\hline Material & 2 hours & 6 hours & I 2 hours & I5 hours & 24 hours & Residue & Total \\
\hline $\begin{array}{l}\text { Succulent young leaves. } \\
\text { Thin young leaves..... }\end{array}$ & $\begin{array}{l}0.30 \\
0.54\end{array}$ & $\begin{array}{l}0.10 \\
0.20\end{array}$ & $\begin{array}{l}0.5 \\
0.8\end{array}$ & $\begin{array}{l}\text { Trace } \\
\text { Trace }\end{array}$ & $\begin{array}{l}\text { Trace } \\
\text { Trace }\end{array}$ & $\begin{array}{l}0.12 \\
0.40\end{array}$ & $\begin{array}{l}0.57 \\
\text { I. } 22\end{array}$ \\
\hline
\end{tabular}

acid salts are absorbed and held in the irreversible aggregation phenomena connected with the processes of drying. It may be mentioned that two series of both kinds of leaves, which by chance were dried much more slowly than the others, showed a difference in the rate at which they yielded up their acid; in both cases the amount which escaped in 2 hours was much less than in the case of the rapidly dried leaves.

When trios of leaves of the 2 types were placed under the auxograph to determine their unsatisfied hydration capacity, swellings as follows (table VII) were displayed at $16^{\circ} \mathrm{C}$.

As will be seen by comparisons with data obtained from Castilleja, the dried mass behaves like the succulent leaves by showing but little expansion after immersion and drying.

Similar tests were applied to sections and to dried median slices of an unknown Opuntia which appeared to be less mucilaginous than O. discata. Dried slices came down to a thickness of 
about $0.2 \mathrm{~mm}$. and these gave swellings at $16^{\circ} \mathrm{C}$. which are to be compared with the swellings of fresh material.

The second swelling produced an expansion scarcely more than half that of the first in all solutions, and being still further decreased in alkali, furnishing striking parallels with the action of succulent leaves of Castilleja.

TABLE VII

\begin{tabular}{|c|c|c|c|c|}
\hline Process & Water & $\begin{array}{l}\text { Citric acid } \\
0.01 \mathrm{~N}\end{array}$ & $\begin{array}{l}\text { Potassium } \\
\text { hydrate } \\
\text { o.oI M }\end{array}$ & $\begin{array}{c}\text { Potassium } \\
\text { nitrate } \\
\text { O. oI M }\end{array}$ \\
\hline 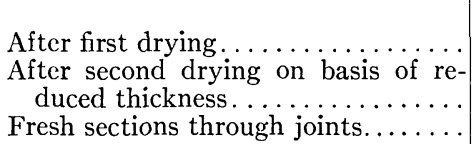 & $\begin{array}{l}\text { Percentage } \\
36 \mathrm{I} \\
\quad \begin{array}{l}42 \\
9.7\end{array}\end{array}$ & $\begin{array}{l}\text { Percentage } \\
306 \\
\quad 56 \\
7\end{array}$ & $\begin{array}{l}\text { Percentage } \\
250 \\
\text { I00 } \\
\end{array}$ & $\begin{array}{l}\text { Percentage } \\
325 \\
\\
75 \\
9 \cdot 3\end{array}$ \\
\hline
\end{tabular}

TABLE VIII

Hydration reactions of succulent and thin leaves of Castilleja; JULY $28-3 \mathrm{I} ;$ AT $16^{\circ} \mathrm{C}$.

\begin{tabular}{|c|c|c|c|c|}
\hline Material & Water & $\begin{array}{l}\text { Citric acid } \\
\text { 0. or N }\end{array}$ & $\begin{array}{l}\text { Potassium } \\
\text { hydrate } \\
\text { o. or M }\end{array}$ & $\begin{array}{l}\text { Potassium } \\
\text { nitrate } \\
\text { o. or M }\end{array}$ \\
\hline Succulent & Percentage & Percentage & Percentage & Percentage \\
\hline Fresh. . & I43 & 95 & I 25 & 90 \\
\hline Swelled and dried & 20 & I6 & 20 & 60 \\
\hline Fresh dried...... & 76 & 60 & 55 & 65 \\
\hline Thin leaves & & & & \\
\hline Fresh. . . . . . . . & I40 & I 20 & 60 & 76 \\
\hline Swelled and dried & I32 & I 2 & 67 & I53 \\
\hline Fresh dried...... & 100 & 20 & I 18 & I30 \\
\hline
\end{tabular}

Two additional treatments of the leaves were given to test the effects of hydration on the swelling capacity of the contained colloids. In one case the trios of sections which had swelled were dried on filter paper for a day at $20^{\circ} \mathrm{C}$., with only enough pressure to prevent warping or curling, then again hydrated in water or the identical solutions of the first swelling. The second case included a swelling of leaves which had been simply dried for a day at $20^{\circ} \mathrm{C}$., in which process they came down to about half the original thickness. The measurements at $\mathrm{I} 7-\mathrm{I} 8^{\circ} \mathrm{C}$., calculated on dried thickness, which was usually about one-half that of living material, are given in table VIII. 
The comparisons which may be made upon the basis of such data are almost endless, and a citation of even the salient features of interest cannot be made briefly. The proportionate hydration of the succulent and thin leaves are reversed in acid and alkali. The succulent leaf, which proves to be one-half as acid as the thin leaf, swells most in the alkaline solution; while the thin leaves, with an acidity double that of the thick succulent ones, have an equivalent maximum in hundredth normal citric acid, and take up only half as much water in the alkaline solution, the disproportion between the two expansions being greater than that of the acid alkali ratio in the succulent.

The thin leaves are characterized by a uniformly high hydration capacity in water in the 3 cases, although reaching a maximum in the salt, a high swelling capacity in acid when fresh, which undergoes a great reduction after drying, while the swelling capacity increases in alkali in parallel treatments. The maximum swelling of the succulent leaves is in water, with great variation in the 3 conditions in which leaves were tested, and with but little variation in the reactions in the salt. The thin leaves, on the other hand, show the maximum and greatest diversity in the salts and more uniformity in water.

The variations in swelling in the acid solution presented such unusual features that an additional series was planned in which thin and succulent leaves in fresh condition were swelled, then such leaves fully hydrated in water and in various solutions were dried and swelled a second time for comparison with the reactions of leaves dried directly from the living condition. Table IX shows the swellings in $0.0 \mathrm{I}$ normal citric acid at $\mathrm{I} 5^{\circ} \mathrm{C}$.

The chief departure from the original series is in the matter of the swelling of the fresh succulent leaves, which in this case appear to have been in such a highly hydrated condition as only to be capable of slight expansion. This assumption is in accordance with the fact that after being immersed and then dried they assumed approximately the original thickness on a second swelling. The thin leaves of this series were consistent in their reactions with those previously examined, showing a relatively small expansion from a dried condition. The conditions making possible the greater variations are evidently those recognizable in the succulent type, 
not the least important feature being the greatly enlarged parenchymatous cells. It is to be seen that immersion and drying, and also simple drying, reduce the swelling capacity of thin leaves in acid, but no such decrease occurs in the succulent leaf.

The principal changes which take place in swelling consist in the extraction of acids and acid salts, as indicated on the previous pages, and of the hexoses as yet undetermined. Any mucilages or pentosans present would of course diffuse at a rate so slow as to be of no consequence in the present experiments.

TABLE IX

\begin{tabular}{|c|c|c|c|c|}
\hline \multirow{2}{*}{ Material } & \multicolumn{2}{|c|}{ THIN } & \multicolumn{2}{|c|}{ Succulent } \\
\hline & Thickness & Swelling & Thickness & Swelling \\
\hline Fresh leaves....... & $\left\{\begin{array}{l}\mathrm{mm} . \\
0.4 \\
0.4 \mathrm{I}\end{array}\right.$ & $\begin{array}{l}\text { Percentage } \\
\quad \text { I } 25 \\
\text { r } 84\end{array}$ & $\begin{array}{l}\quad \mathrm{mm} . \\
\mathrm{I} .4 \\
\mathrm{I} \cdot 4\end{array}$ & $\begin{array}{l}\text { Percentage } \\
\quad 2 \mathrm{I} \\
\quad 25\end{array}$ \\
\hline $\begin{array}{c}\text { Above leaves dried and rehy- } \\
\text { hydrated }{ }^{*} \ldots \ldots \ldots \ldots \ldots \ldots \ldots\end{array}$ & $\left\{\begin{array}{l}0.23 \\
0.25\end{array}\right.$ & $\begin{array}{l}42 \\
20\end{array}$ & $\begin{array}{l}0.5^{-0} .6 \\
0.63\end{array}$ & $\begin{array}{l}95 \\
91\end{array}$ \\
\hline Fresh dried leaves*. & $\left\{\begin{array}{l}\left(0.3^{8}\right) \\
0.2 \\
\left(0.3^{8}\right) \\
0.2\end{array}\right.$ & $\begin{array}{r}\cdots \cdots \\
25 \\
\cdots \cdots \\
62\end{array}$ & $\begin{array}{c}(\mathrm{r} .2) \\
0.5 \\
(\mathrm{r} . \mathrm{r}) \\
0.38\end{array}$ & $\begin{array}{c}\cdots \ldots \ldots \\
\text { r } 20 \\
\cdots \ldots \ldots \\
92\end{array}$ \\
\hline
\end{tabular}

* Expansion in terms of dried thickness.

The swelling of fresh leaves of both types in water reaches the limit in less than 2 hours, the rate of extraction of acid in the 2 types of leaves being equivalent, and the proportionate expansions not widely different. When such leaves are dried the thin leaves attain the limit in water inside of 2 hours, while the succulent leaves continue to expand for 6 hours with an escape of acid about half that from the thin leaf during the same time.

If attention be turned to the reactions in acids, it is seen that thin leaves swell more than succulents in such solutions when fresh, and that the swelling extends over a greater length of time, while the total swelling in a dried condition is accomplished in a few minutes. The succulent leaves, on the other hand, require a period of as much as 6 hours to reach full hydration from a dried condition.

While the effect of the residual acidity is discernible in some of these relations, it is evident that this factor is not the dominating 
one. Two other features remain to be considered, that of the composition of the plasmatic colloids, and of the salts dissolved in the water of hydration. The colloids of living leaves are highly hydrated, and the salts, acids, etc., are also in a highly dilute condition, in which case their effect would be at a minimum. Death and desiccation would be accompanied by a concentration of these compounds, until finally they would be adsorbed by the cell walls and plasmatic colloids in their most concentrated condition with resulting coagulations, some of which in all probability are irreversible. The thin leaves have a higher acid content, and, to anticipate, a smaller proportion of pentosans which would accentuate this effect, hence the relatively low coefficient of swelling from a dried state. A long series of experiments with sections of dried colloids and of living and dried plants of known composition make it appear that the water relations of active tissues show the behavior of a biocolloid consisting largely of pentosans, of which agar or plant mucilages would be an example, a small proportion of protein or protein derivatives, and some salts and free acids. ${ }^{4}$ It is to these features, therefore, that one would naturally turn for the factors which might increase the water-holding capacity of the cell or organ, and in so doing the pentosans would claim attention first. These substances probably are always present in some proportion in cells, and their occurrence is therefore not significant. Any action or condition which brings about a notable increase in their proportion in the cell would have most important consequences however. Such increase does result from a depletion of the water of a cell, for the polysaccharides under such conditions are reduced to the pentosans, and the reduction of the water content of a cell results in the conversion of the polysaccharides, which do not show marked imbibition, to pentosans, which take the form of an elastic gel with an enormous capacity for expansion, particularly when mixed with nitrogenous material, and upon this rests the hypertrophies or hyperplasias of thin-walled tracts in the development of

4 MacDougal, D. T., Imbibitional swelling of plants and colloidal mixtures. Science $44: 502$. I9I6.

MacDougal D. T., and Spoehr, H. A., The effect of acids and salts on biocolloids. Science $45: 269^{-272}$. I9I 7 .

- Growth and imbibition. Proc. Amer. Phil. Soc. 56:289-352. I9r 7 .

- The behavior of certain gels useful in the interpretation of the action of plants. Science $45: 484-488$. I9I 7 . 
succulence in an organ. Briefly restated, whenever the water content of a cell becomes low, some of the hexose-polysaccharides, which have a low imbibition capacity, are converted into pentosans, which have a high hydration capacity, the action having the force of a regulatory adjustment, and as the change is irreversible, the pentosans are accompanied by a permanent succulence, with all of the implied alterations in metabolism, ${ }^{5}$ including a very striking change in the type of respiration, or of transformations in the carbohydrates. $^{6}$

It is notable that, while this change in the sugars takes place in the cell, the type of transformations of energy changes completely, but the approximate rate of respiration is not materially affected. The nature and amount of the end products, however, may differ materially from those of a respiration in thin leaves, notably in the acid residues. It is in the mesh of reactions indicated that the origin and the nature of succulence will be found, and whatever causal value is attributed to the action of soil salts or of arid conditions will rest upon their part in the conversion of the polysaccharides to pentosans.

Acidity in succulents has been attributed by many writers, including the authors of this article, to the imperfect oxidations resulting from the lessened aëration of massive tissues, leaving a residue of malic acid, for example. Castilleja, however, presents the example of highly acid thin leaves, which become succulent under conditions similar to those which favor the transformation of polysaccharide to pentoses in other plants. Instead of acidity being a direct result of succulence, it is much more reasonable to conclude that high acid residues may be characteristic of plants which present a metabolic complex favorable to pentose formation and to the development of succulence under certain environic conditions.

5 Spoemr, H. A., The pentose sugars in plant metabolism. Plant World 20:365. I9I8.

${ }^{6}$ MacDougal, D. T., and Spozhr, H. A., The origination of xerophytism. Plant World 2r: 245-249. I9I8.

Coastal Laboratory

Carmel, California 